\title{
Deteriorating inventory model using preservation technology with salvage value and shortages
}

\author{
Mishra, V.K. \\ Department of Computer Science \& Engineering, Bipin Tripathi Kumaon Institute of Technology, Dwarahat, Almora, India
}

\begin{abstract}
A B S T R A C T
In this paper, we attempt to develop an inventory model for deteriorating items with the consideration of the fact that the use of preservation technology (PT) can reduce the deterioration rate significantly. In this model the shortages are allowed and salvage value is incorporated to the deteriorated items. Demand rate is constant, deterioration rate is time dependent with Weibull's distribution. The model is solved analytically by minimizing the total cost of the inventory system and the numerical and graphical analysis is provided to illustrate the solution and application of the model. This analysis of the model shows that the solution of the model is quite stable. The model can be applied for optimizing the total inventory cost of deteriorating items inventory for the business enterprises where they use the preservation technology to reduce the deterioration rate of the inventory items.

(C) 2013 PEI, University of Maribor. All rights reserved
\end{abstract}

\begin{tabular}{l} 
A R T I C L E I N F O \\
\hline Keywords: \\
Inventory \\
Deteriorating items \\
Shortages \\
Preservation technology \\
Salvage value \\
Weibull's distribution \\
Corresponding author: \\
vkmishra2005@gmail.com \\
(Mishra, V.K.) \\
Article history: \\
Received 1 July 2012 \\
Revised 15 August 2013 \\
Accepted 23 August 2013
\end{tabular}

\section{References}

[1] Whitin, T.M. (1957). The theory of inventory management, $2^{\text {nd }}$ ed., Princeton University Press, Princeton, NJ.

[2] Ghare, P.M., Schrader, G.F. (1963). A model for an exponentially decaying inventory, Journal of Industrial Engineering, Vol. 14, 238-243.

[3] Philip G.C. (1974). A generalized EOQ model for items with weibull distribution, AIIE Transactions, Vol. 6, No. 2, 159-162.

[4] Dave, U., Patel, L.K., (1981). (T, Si) policy inventory model for deteriorating items with time proportional demand, Journal of Operational Research Society, Vol. 32, 137-142.

[5] Hollier, R.H., Mak, K.L. (1983). Inventory replenishment policies for deteriorating items in a declining market, International Journal of Production Research, Vol. 21, No. 6, 813-826.

[6] Deb, M., Chaudhuri, K.S. (1986). An EOQ model for items with finite rate of production and variable rate of deterioration, Opsearch, Vol. 23, 175-181.

[7] Goyal, S.K., Giri, B.C. (2001). Recent trends in modeling of deteriorating inventory, European Journal of Operational Research, Vol. 134, No. 1, 1-16.

[8] Teng, J.T., Yang, H.L. (2004). Deterministic economic order quantity models with partial backlogging when demand and cost are fluctuating with time, Journal of the Operational Research Society, Vol. 55, No. 5, 495-503.

[9] Yang, H.L. (2005). A comparison among various partial backlogging inventory lot-size models for deteriorating items on the basis of maximum profit, International Journal of Production Economics, Vol. 96, No. 1, 119-128.

[10] Ouyang, L.Y. (2005). An inventory model for deteriorating items with exponential declining demand and partial backlogging, Yugoslav Journal of Operations Research, Vol. 15, No. 2, 277-288.

[11] Wu, K.S., Ouyang L.Y., Yang, C.T. (2006). An optimal replenishment policy for non-instantaneous deteriorating items with stock-dependent demand and partial backlogging, International Journal of Production Economics, Vol. 101, No. 2, 369-384.

[12] San José, L.A., Sicilia, J., García-Laguna, J. (2006). Analysis of an inventory system with exponential partial backordering, International Journal of Production Economics, Vol. 100, No. 1, 76-86, doi: 10.1016/j.ijpe.2004.10.012. 
[13] Dye, C.Y., Ouyang, L.Y., Hsieh, T.P. (2007), Deterministic inventory model for deteriorating items with capacity constraint and time-proportional backlogging rate, European Journal of Operational Research, Vol. 178, No. 3, 789-807, doi: 10.1016/j.ejor.2006.02.024.

[14] Alfares, H.K., (2007). Inventory model with stock-level dependent demand rate and variable holding cost, International Journal of Production Economics, Vol. 108, No. 1-2, 259-265, doi: 10.1016/j.ijpe.2006.12.013.

[15] Roy, A. (2008). An inventory model for deteriorating items with price dependent demand and time-varying holding cost, Advanced Modeling and Optimization, Vol. 10, No. 1, 25-37.

[16] Skouri, K., Konstantaras, I., Papachristos, S., Ganas, I. (2009). Inventory models with ramp type demand rate, partial backlogging and Weibull deterioration rate, European Journal of Operational Research, Vol. 192, No. 1, 7992, doi: 10.1016/j.ejor.2007.09.003.

[17] Mishra, V.K., Singh, L.S. (2010). Deteriorating inventory model with time dependent demand and partial backlogging, Applied Mathematical Sciences, Vol. 4, No. 72, 3611-3619.

[18] Abad, P.L. (1996). Optimal pricing and lot-sizing under conditions of perishability and partial backordering, Management Science, Vol. 42, No. 8, 1093-1104.

[19] Abad, P.L. (2001). Optimal price and order-size for a reseller under partial backlogging, Computers and Operation Research, Vol. 28, No. 1, 53-65, doi: 10.1016/S0305-0548(99)00086-6.

[20] He, Y., Wang, S.Y., Lai, K.K. (2010). An optimal production-inventory model for deteriorating items with multiplemarket demand, European Journal of Operational Research, Vol. 203, No. 3, 593-600.

[21] Mandal, B. (2010). An EOQ inventory model for Weibull distributed deteriorating items under ramp type demand and shortages, Opsearch, Vol. 47, No. 2, 158-165, doi: 10.1007/s12597-010-0018-x.

[22] Chang, C.T., Teng, J.T., Goyal, S.K. (2010). Optimal replenishment policies for non-instantaneous deteriorating items with stock-dependent demand, International Journal of Production Economics, Vol. 123, No. 1, 62-68, doi: 10.1016/j.ijpe.2009.06.042.

[23] Hung, K.C. (2011). An inventory model with generalized type demand, deterioration and backorder rates, European Journal of Operational Research, Vol. 208, No. 3, 239-242, doi: 10.1016/j.ejor.2010.08.026.

[24] Mishra, V.K., Singh, L.S. (2011). Deteriorating inventory model for time dependent demand and holding cost with partial backlogging, International Journal of Management Science and Engineering Management, Vol. 6, No. 4, 267-271. 